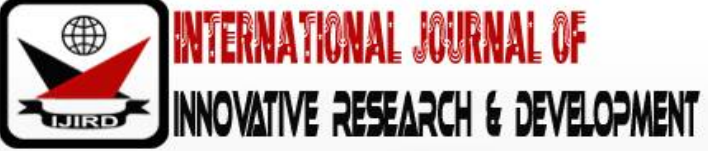

ISSN 2278 - 0211 (Online)

\section{Organizational Structures, Institutions and Administrative Systems in Pre-Colonial African States: A Discourse}

\author{
Adeyemo Babatunde Adeoye \\ Lecturer, Department of History, Aminu Saleh College of Education, Azare, Nigeria
}

\begin{abstract}
Contrary to some scholars' views, pre-colonial African societies did not lack political organization. African societies developed diverse political systems based on local needs and realities before the advent of the Europeans. Like the 'centralized' states, the 'acephalous' societies, that is, stateless societies, also evolved a decentralized government based on kinship and lineage system. There has been timeless controversy over the nature of government in what has been variously referred to as the 'decentralized' or 'segmentary polities; the argument here however, is that since human societies have been seen as evolving from hunting and gathering bands to more units like the state, and since they have embodied in their very networks the seeds of strains and conflicts, societies differ in the way they try to tackle problems emanating from interactions; and therefore, the maintenance of social equilibrium, cohesions, and the all-important question of peace. This paper argues that if the purpose of government is the promotion of the welfare of the populace, then the pre- colonial African societies had all the attributes of government; the interactive dynamic process of which a balance between power and authority was ensured on the one hand, and service and accountability on the other.
\end{abstract}

Keywords: Centralized societies, pre-colonial period, decentralized government, kinship and lineage system

\section{Introduction}

Before the coming of colonialists, the history about the level of developments that of Africa is very contentious. Africa has been considered as having inferior history in the eyes of the world history. The Africans are believed not to have contributed to anything found in Africa that was considered an achievement. Before the coming of whites, the continent was dark, uncivilized and no any development took place. This view is widely expressed in the writings of leading western scholars who believe that the historical movement and development, which hitherto took place in Africa belong to the Asiatic or European World. For example, the German philosopher, George Hegel, a Eurocentric scholar wrote,

"Africa is not a historical continent; it shows neither change nor development.... At this point we leave Africa, not to mention it again. For it is no historical part of the World: it has no movement and development to exhibit".

There was development of diverse systems of political organizations. If we are to use social formations approach, it becomes easier to identify certain similar and common patterns and developments. Communalism and the high community modes of production were the most common social formations by the $19^{\text {th }}$ century. Feudal relations of production had been developed in some parts of the continent. Slavery had developed in some coastal states. To assess the African states' organization structure, institutions and administrative systems before the coming of the Europeans is the main focus area of this paper.

In pre-colonial Africa, significant heterogeneity in political organization was noticed. It has been noticed that states with an authority system in consolidated format and having a pre-defined arrangement like Oyo Empire and Hausa city, Nigeria. It is also quite similar with Ashanti kingdom, the kingdoms of Buganda and Ankole in Eastern Africa. On the other hand, some are communities without state like division (acephalous societies), like Igbo in eastern Nigeria. Like the Neur in Sudan, the Konkomba in Ghana and Togo there is no division after village. Taking about central, alliances are formed in chieftaincy. This is alike with Ewe and Wolof of Western Africa. With this type of alignment, they are showing interest for a procedure to handle dispute and an integrated and centralized system for making decisions.

However, most of the available scientific evidence suggests that Africa was a continent of many histories. The societies developed beyond primitive communal life long ago. The Africans had tried to forge political, social, and economic institutions for proper management of their affairs, thus even before the landing of the foreigners, the continent had already developed in all aspects; politically, economically, technologically, and socially. Meanwhile before we proceed, we need to acquaint ourselves with how the various societies metamorphosed from one mode of production to another in order to understand that each of those modes of production was a result of a long process of historical development. These pre-colonial modes of production are: 
- Antediluvian allegiance

- Slave mode of production; and Bondage

\section{Antediluvian Allegiance}

This was the first mode of production. Under this life are owned and should be shared by all community members. About two (2) million years ago, when man started life on the earth, and other mode of production in Africa this mode of production come into picture. Here people organized themselves in small communities according to their blood relationship, and performed different activities together. Bands of individuals grouped together and lived by hunting and gathering, sharing the common booty or common finds equitably. This was the first mode of production through which all societies passed through.

\subsection{Characteristics of Antediluvian Allegiance}

- Communal ownership of the major means of production. The organization of socio-economic life under this mode of production was based on the principle of common ownership of land, and all other means of production. No one could privately own anything concerned with production.

- Absence of exploitation of man by man. One differentiating feature of this mode of production from the rest is its non-existence of exploitation in society. All able-bodied people participated in production and what was harvested was equally distributed.

- Hunting and gathering were the major activities. For long time that primitive communalism existed, man had not yet started mastering his environments, thus his life was absolutely dependent on what nature produced, without any practical assistance of their part. Man lived a hunting and food-gathering life.

- Equality to all members of community. It was classless society. No one was superior or above others; all the members of community were equal and equally participated in community activities.

- Presence of full democracy, in primitive communalism all decisions had to be arrived at by all the adult members of the group regardless of their sex. Adult had no coercive power and instead they exercised their power purely through respect and need.

- No surplus production. Affected by the low level of science and technology, in primitive societies, labor was not very productive and could not produce more than the amount essential for life.

- Low level of science and technology. It was the period when man used stone made tools in the struggle to obtain his basic necessities for life. The level of science and technology was very low.

\section{The Slave Mode of Production}

The second mode of production in human history was slavery. Slavery is the situation whereby an inferior person is owned, controlled and used by the other superior one as an instrument of labour. This was the second mode of production and the first exploitative mode of production in which human was used by other human in production. Unlike primitive communalism, here the population in society was divided into two antagonistic classes; slaves, and the slave masters. The slaves owned nothing than their labour. They were used to perform different masters' activities under strict oppression and exploitations.

Debates still rage as to whether Africans practiced slavery as the mode of production or not. Many historians do agree that slavery never occupied central place in the political, economic, and social life of pre-colonial African societies. In European communities, when communalism broke down, it gave way to slavery mode of production. This slavery continued until the middle ages. This was quite different in Africa. It is important to note that political systems based on slavery relations of production were very few in Africa South of the Sahara because the slave mode of production had not been widely developed. The few cases of slavery relations grew along coastal trading city states such as those in West Africa where the city states had been centres of slave trade for a number of centuries. Yet, slavery existed in the aforementioned areas was not of the same type of slavery that the Europeans practiced. Slave labor in Egypt for example, was used in the construction of dams and pyramid buildings.

\subsection{Why Did African Societies Not Develop Slavery Mode?}

- Hunting and gathering were the major activities in Africa. Slaves were largely involved in productive labour. It was rare in hunting and gatherers societies.

- Many societies lacked centralized governmental institution to enforce slavery. Kinship formed the core of African pre-colonial societies.

- Long existence of primitive communalism. In Africa, there was no slaves, and certainly no epoch of slavery.

- Absence of perpetual exploitation.

\subsection{Characteristics of Slavery}

- Existence of classes. the society in slave mode of production was split into two antagonistic classes, the slaves who owned nothing than their labour, and the slave masters who were dominant over everything including slaves.

- Exploitation of man by man. Slaves in this mode of production were victims of their masters' exploitation. They provided their labour to their masters' farms with low payments and sometimes without payments at all. The slave master benefited with the surplus products produced by slaves. 
- Private ownership of major means of production. The major means of production such as land, farms, machinery and slaves were no longer collectively owned under this ode of production, but all owned privately by individual person called slave master.

- People started producing surplus. At this stage, surplus was now produced. This was due to minor advancement in level of science and technology which eventually improved productive forces.

\section{The Feudal Mode of Production}

\subsection{This Is another Mode of Production Focused on Land}

Latin word "feudum" means "a piece of land" which can be given on rent is the origin of feudalism. Many landless people had got land from people who had enough land.

The amount of land one owns reflects one's power and money. The more land one has, the more influential he is. In terms of money many transactions had taken place. Suitable for cultivation many relations had been established. Feudalism has many names like Nyarubanja, Nvunjo and Busulo. Obugabire means livestock, is the main development basis for feudal relationship among the Tutsi and Hutu of Rwanda, Burundi and Buha. Umwinyi, was a type of feudalism in the coast of east Africa and Zanzibar. In the 19th century, feudal -based kingdoms were few. From Ethiopia, Buganda and other states in the East African Interlacustrine Region had some typical examples of this type of mode of production. For example, the East African Coast was politically organized through sultanates, which controlled land as well as trade, monetary aspects etc.

\subsection{Characteristics of Feudalism}

- Existence of classes: The society in this mode of production was split into two antagonistic classes, the feudal lords who were the owners of land and tenants whose lives depended on renting land from the former.

- Exploitation of man by man: Peasants/ tenants were victims of exploitation by their feudal lords. Exploitation was affected through renting. Feudal lords' lives substantially depended on their tenants' rents.

- The major means of production based on land: Man, in this stage had already mastered his environment, was cultivator and animal keeper. Land therefore was the major means of production.

- People started producing surplus: At this stage, surplus was now produced. This was due to minor advancement in level of science and technology which eventually improved productive forces.

- Private ownership of major means of production: Land as the major mean of production was no longer collectively owned under this ode of production, but all owned privately by individual person called feudal lords or landlords.

- Presence of classes: In feudalism, there existed classes in the society, there was the class of the serfs which owned their labour power and the class of feudal lords which owned the major means of production such as land or cattle.

- Political developments: As agriculture kept people permanently there emerged complex communities like Buganda, which in turn demanded strong political authority to govern people in distribution of land and many other duties. Here there was development of political systems.

\subsection{Types of Feudal Rents}

As already mentioned, peasants who occupied and tilled the land were not its owners. Thus, they paid rents, which were in three categories, namely;

- Labour rent: In this type of rent, peasants who were given plots of land were obliged to work the land owner's land using their own implements. Tenants had to first to work in their plots for their survival, and for some days in their master's plots as rent.

- Rent in kind: In this type of rent, serfs were supposed hand over part of their output or harvest to the land owners. Here tenants had no longer the duty of working in their master's plots, worked only in their plots and took part of their harvests to the landlords.

- Money rent, after the emergence of money economy, serfs were obliged to sell their harvest and hand over the agreed amount of money to the landowners as the rent for the usage of the land.

\section{Transition from Primitive Communalism}

As already noted above, pre-colonial societies were neither static no classless. They developed beyond primitive life. At the arrival of whites in the $15^{\text {th }}$ century, some societies had already developed class mode of production. However, majority of pre-colonial African societies did not pass through slave mode, but directly shifted to feudalism. The following are some reasons for transition from primitive communalism to feudalism.

\subsection{Shortage of Land}

This was certainly the main factor for development of feudal relations. With shortage of lad people started to struggle for land, thus few who were powerful emerged owners and majority landless became tenants of land. 


\subsection{Geographical Factor}

Some societies were lacked having fertile soil and reliable rainfall. This attracted people from different directions, the result of which there emerged very complex society which made it necessary for the existence of feudalism.

\subsection{Expansion of Agriculture}

Being based on the ownership of land feudalism could not develop in the moment man depended on hunting and gathering. Thus, commencement of crop cultivation and animal rearing was crucial factor for the development of feudalism as it made land very demanded asset in society.

\subsection{Advancement of Science and Technology}

With the discovery of iron in pre-colonial societies, land was again made very useful asset as it enabled man to clear large areas for cultivation. This attracted feudal relations.

\subsection{Development of Trade Activities}

Surplus production led to development of trade relations among the communities. This encouraged people to cultivate more and more for trading. Again, even those societies which did not have iron ores could access iron tools from neighboring communities through exchange.

\subsection{Growth of Population}

As the production increased, the number of people doubled in pre-colonial societies. This resulted to shortage of land, thus people started to struggle for it. Some became dominant some tenants over others.

\section{Political Development in Pre-Colonial Africa}

As already discussed above, even before the whites' colonization took place toward the end of the 19th century, the African societies, had generally everywhere progressed beyond the stage of primitive communism. This development also involved political aspects. People knew how to control their own affairs, make laws, and settle disputes among themselves. Pre-colonial African communities were not homogenous and they took on varying characteristics in regard to governance, depending on the context they were located. Different systems of government existed from the very beginning, which were responsible in organizing people for the material production and social interaction. Village-style government with a council of elders and/ or village chiefs predominated in hunting and gathering and small agricultural societies. Strong centralized governments under strong leaders capable of collecting taxes, regulating commerce, and mobilizing armies were common in intensive-agriculture societies like Egypt, Nubia, Ethiopia, Ghana, Mali, and Songhay. Historians have identified three types of political organizations that evolved in pre-colonial Africa. These were as follows:

\subsection{Communalism Influenced Political Organization}

Political orientation of Africa was quite focused for development of social formations. This time was the middle of the 19th Century. They focused mainly on production. Primitive communalism relied on hunting and gathering. Whereas, advanced communalism had showed much more socio-economic development. Many developed economic activities for agriculture had been noticed with more advanced soil preparation. Livestock was another development in this era. Very close to $70 \%$ of society had started following these activities and a small portion were depending on primitive one. Kinship or livings in clans are the most common form of organization. Organization has been formed on blood relation basis. Head was the chief. As no such huge improvement of technology was there, chef was mainly focusing on how labors could survive. Aged persons were being treated most important source for making decisions. Many meetings were being held for this purpose by them. Generally, a participatory approached were followed in community. Many age-divisions were there like senior elders, elders, young people and children. Each segment had its own political leadership. Each clan of Africa had its own type or case studies. Like Kenya had most kinships similar with the Kikuyu, the Kamba and the Nyika. The Masai and Nandi had age-set structure in society. Uganda had both. Ntemi political systems were being followed in the Wagogo, Wanyamwezi, Wasukuma etc.Wayao, Wamwera, Waluguru, Wazaramo, Wamakua, and Wamakonde had been seen to follow matrilineal societies.

\subsection{The Age-set Organization}

One of the most distinctive socio-political systems in pre-colonial Africa was the system of age-sets. Age-set means a group of people whose age falls within a certain limit. This was the social and political organization mostly developed in pastoral societies, in which age was the criteria for the allocation of duties and responsibilities among the members of the community. Although many pre-colonial societies practiced this system, it was more dominant in pastoral societies like Masai of East Africa, Galla of Somaliland, Hottentos of Southern Africa, Fulani of western Sudan and many others. Most of these societies remained politically not advanced and hence, practiced age-set organization due to;

\subsubsection{Nomadic Nature of Life}

The pastoral societies are in constant movements from place to place with their animals. It is very difficult to organize themselves in a strong political institution without having permanent recognized settlements. 


\subsubsection{Nature of Their Economic Activity}

Livestock demands continuous care and attention, further demands great efforts in search of pasture land and water holes. Here there was a need to have organized themselves in age-set groups.

\subsubsection{The Arid Nature of the Areas They Settled}

Mostly pastoral societies settled in arid and semi-arid regions, in which there was little rainfall which only supported the growth of pastures.

They needed a group of people to defend the societies with their wealth. Livestock keeping requires an efficient system of mobilizing the Youngman for defense. Such combined efforts could not be possible with the family or clan organization.

\subsection{Example of Division of Responsibilities in Masai Societies}

- $\quad$-----8 years: very young boys stayed at home helping their mothers in domestic activities. They did not have any production duties.

- 8----18 years: youth who basically looked after cattle, goats and sheep (grazing). They also helped in milking cattle. The young boys and girls in this group were supervised by women.

- 18-----40 years: These were called Moran; these were the youth and matured people in the society. The main duties of Moran in the societies were as follows; Protecting their society as specialized soldiers against external attacks, protecting livestock against wild animals and thieves, Increasing the size of their cattle herd through frequent raids and bringing home the captured animals, and traveling to distant places with their cattle seeking pastures and water especially in the dry season and drought.

- 5BVGFTR40 years and above: Elders, these controlled livestock and other property in the society on behalf of the community. Elders were divided into junior elders, the elders and senior elders. The senior elders were called Laibon and had special respect as political and religious leaders. All leaders were not directly involved in production; however, they were called retired officers. Elders had the following responsibilities: Giving counseling to the other groups, performing rituals and providing religious leadership, and Offering wisdom to their society.

\subsection{Advantages of Age Set System.}

The age set organization produced a well-disciplined and hardworking people who were/ are responsible to their society.

The age set organization ensured a fair and equally distribution of labour in the society, every able person in the society participated in working.

It provided strong defense system for livestock and other properties of the society. This was due to the division and specialization of labour as it created special group of people for the work of defending.

The age set organization created stability within the pastoral society, there was strong and stable leadership based on age set groupings.

\subsection{Centralized Political Systems}

In many parts of Africa centralized political systems had developed and in some cases were beginning to develop. In these systems you had state organizations that covered larger territories, incorporating several clans and kinship groups. However, we can categorize centralized state systems into two stages of development: the first was the stage of centralized states, and the second was that of advanced centralized states.

Centralized states which had developed in many parts of Africa were based on the high community relations of production. In this type of social formation, a ruling aristocracy had emerged which exercised political authority on peasant communities. The ruling aristocracy exerted political control over land and even livestock although actual ownership was still communal-based through villages, clans and even families. The Mode of appropriation was through appropriation of surplus product by members of the ruling aristocracy rather than appropriation of nature and of the soil as was the Case under primitive and advanced communalism. The Ashantehene and Benin Empires in West Africa, the Ndebebele state in Zimbabwe, the Zulu Empire in South Africa, and the Shambaa, Hehe, Ngoni and Nyamwezi (Mirambo) Empires in Tanzania provide but few examples of centralized states in different parts of the Continent.

It is not easy to draw a clear distinction between centralized and advanced or more highly centralized states. The latter presupposes emergence and development of feudal relations of production in which the ruling aristocracy not only controlled land and livestock but also assumed considerable levels of private ownership of land. Like under high community relations appropriation was based on appropriation of surplus product. In most cases the rulers were very powerful kings.

\section{Africa's World View of the Supreme Being (God)}

Like sub-Saharan Africa, supreme beings of Africa are spiritual. Among people of age 60 and above belief in Supreme Being is common. Unique and different qualities are found among them. Prior to the Christianity and Islam, aboriginal, conservation religious priority reflected through the characteristics and attributes of the African Supreme Being. Hence among African peoples' traditional socio-political structures and languages diversity found.

Association towards many aboriginal cultures was found by African Supreme Being. Among supreme beings, certain similarity notice in nature and characteristics although cultural and linguistic differences exist. Fallacy exists among several groups of Africa about their supremacy and intrinsicness. Varying behavior noticed among social pecking i.e. 
relationships between family members, connections with natural incidents. It is believed that the sky, the earth, and the underworld are interconnected to the Supreme Being. It is believed that supreme beings are mainly responsible behind the creation of above-mentioned elements. Astrophysics related fallacy talked about many actions in terms of political and social among this diverse group. Instead of creating localities supreme beings are mainly the creator of community. Hence, they are being considered as summit of the cosmic structure of entire creation. Their importance also acclaimed by society and political fields of Africa. Always variety of fallacies has been discussed by many generations as well as by clergyman in native languages.

\subsection{Local Geography based Supreme Beings}

For the purpose of this study supreme beings from various parts of Africa-East, West, Central, and southern Africa-include Amma, Nyame, Ngewo, Olódùmarè, Osanobuwa, Chukwu, Kwoth, Mulungu, Nzambi, Nhialic, Ndjambi, Ngai, and Unkulunkulu have being discussed.

\subsection{The 'Unkulunkulu' of the Zulu People of South Africa}

There is some enigma about the development of Unkulunkulu, a supreme deity among the Zulu people in South Africa.Unkulunkulucame from Zulu language denotes great, great one" or "old, old one". They are also called Mvelinqangi, which means "'the first outcomer" known as ancestor of all. Unkulunkulu with Uthlanga are called the first man. They are believed to be created by breaking of quill. All humans are said to be derived from the first outcomer" human being, "the first man," and "the ancestor of all,"; the Unkulunkulu. The status of them are equivalent of Christian missionaries. From oral histories, narratives, and communal or corporate rituals facts of Unkulunkulu can be known. It is believed among Zulu that they are the creator. Without them marriage and chieftainship are not possible. They could reveal the hidden things of the past and future, and doctors who would treat various diseases among the people.

\subsection{Mulungu (Bantu and Sudanese of East Africa)}

For the Yao and Zimba of Malawi and Mozambique, the Kamba of Kenya, and the Gogo of Tanzania, Mulungu is the chief god of most Bantu-speaking peoples of East Africa.

Mungu or Muungu, Mungu, Murungu, and Mvungu.Mulungu (more than forty Bantu languages) is the name of the Supreme Being for people peaking Swahili from East and Central Africa.

Mumbi, originated from verb "to create" or "to bring into existence," is the previous well-known name for Bantu. All of the names of Supreme Being in terms of meaning are almost same although a huge variation exists. Ultimately all indicates almighty and ever-present creator. Astronomically, sky is the house of him, voice is thunder and power is lightning. He punishes evils and reward the good. Drought happens when he is angry. Yao myth, an African creation myth describes Mulungu as animal present from beginning. As per myth chameleon, an animal found two human beings while fishing trapped in its net. After taking them to Mulungu, it ordered them to free and let them grow in earth. Chameleon after getting order from Mulungu taught the human beings to create fire. But human could not control fire which burned the earth and through spider spun drove Mulungu in the heaven. Mulungu is still interacting with human beings especially when they disobey morality. Tender-hearted Mulungu has no formal religious veneration. He is the owner who is the judge and presents everywhere. Those who dwell and request for ensuring their decency prayers are directed to lesser spirits.

\subsection{Olódùmarè and Ọlọrun}

Yoruba people, southwestern Nigeria based urbanized society with large city-state believed Olódùmarè as supreme God. It is difficult to find its origin but as per mythology he is the almighty, the first being, and the creator. It has relationship with sky- Olọ́run. Although he is the creator but many myths -- some myths say 201, some say 401, and some say 601, divinities or òrișà are there to execute his order. Some òrisàcreate, some maintain the world. They also smooth the social and psychological spaces of the human life. Each òrìsàworks in separate area. Ọbàtáálà, Ộrúnmìlà, Odùduwà, Òșun, and Òguń are getting created by òrìsà.

Some others are there to maintain ordered and moral behavior. Eșù supervises sacrifices those are directed to clients through divination. For creation of world he has dry soil, a five-toed hen, and a chameleon.Obàtáálá got dry soil from Olódùmarè for the world. Five-toed hen then spreads the soil.

Another myth discussed that Odùduwà has to complete the creation as Obàtáálá gets drunk on the way to the world. Olódùmarè got pleased with the test of chameleon and work of five-toed hen.

Yorùbá mythology talked that ọ̀rúnmìlà is the subaltern of Olódùmarè regarding knowledge and wisdom. Destiny is being shaped by Àjàlá. Every hyman can select from several heads coming from heaven which contains experience of life. Yoruba concept said that god is not accountable for human catastrophe. Olódùmarè also helps to reduce human sufferings. Olódùmarè and deities are involved in the processes of controlling human beings and their activities. The ordering of sacrifices by Olódùmarè explains the complexities of human beings. There is a continuous relationship between human being and Olódùmarè. Characteristics of human are being explained by divinities as Òguń, Saǹgó, ọșun, Oya, and several others. They further explain angriness and passion of Olódùmarè. Provisions and securities are also provided by them with dedication and abundant harvest. Their prayers also provide help for human in need.

\section{Conclusion}

There was equal heterogeneity in political centralization across African ethnicities before colonization. At the one extreme, there were states with centralized administration and hierarchical organization such as the Hausa states in Nigeria, the Luba kingdom in Central Africa and the kingdoms of Buganda and Ankole in East Africa. At the other extreme, 
there were stateless societies otherwise called 'acephalous' societies. These are states without political organization in the sense of western model and they include the Nuer in Sudan, the Konkomba in Ghana and Togo, and the Igbo of Southeastern Nigeria.

From the foregoing it can be deduced that if the purpose of government is the promotion of the welfare of the populace, it then goes to show as it has been indicated above that African societies, despite their supposed backwardness politically, had evolved socioeconomic, cultural, political and religious institutions that had all the attributes of government. In the traditional political organization of the people, there was a balance between power-authorityand service-accountability. Leaders were never given ultimate power while office holding was predicated on proven merit. The problem with this type of socio-political organization however, was that all the organs of government were fused together in such a way that to subtract one of the organs from the rest means the abrupt disruption of the whole system.

\section{References}

i. Armstrong, R.G. (1960) The Development of Kingdoms in Negro Africa', Journal of the Historical Society of Nigeria, 12(1), 1960, 22 - 63.

ii. Awolalu, J. O. and Dopamu, P.A. (1979) West African Traditional Religion. Ibadan, Nigeria,

iii. $\quad$ Dudley, B.J. (1968) 'Parties and Politics in Northern Nigeria', London: Frank Cass.

iv. $\quad$ Eisenstadt, N. (1954) 'African Age groups', African 1(24), pp.100 - 113.

v. Elaigwu, J.I. (1975) 'Self-Regulation in a Traditional Society; Integration and Order in Pre-colonial Otukpo of Nigeria', Monthly Newsletter, 5(2), pp.13 - 18.

vi. Erim, E. O. (1984)Idoma Nationality, 1600 - 1900: Problems of Studying the Origin and Development of Ethnicity, Enugu: Fourth Dimension Publishers, pp.94 - 95.

vii. Horton, R. (1976) 'Stateless Societies in the History of West Africa' in A. Ajayi and M. Crowther (eds) History of West Africa. Vol. 1, London: Longman Group, pp.72 - 113.

viii. Idowu, E. B. (1973) African Traditional Religion: A Definition. London.

ix. Jones, J.J (1963) The Trading States in the Oil Rivers', London: Oxford University Press.

x. Middleton, J. and Tait, D. (1958) Tribes without Rulers', London: Routledge and Kegan Paul, 1958, pp. 1 - 31.

xi. Okpeh, O.O. (1991) Jr., The Historical Evolution of the Ochobo clan in Oglewu District of Otukpo

xii. Local Government of Benue state, 1900 - 1960, B. A. Thesis, University of Jos, Jos, Plateau state, July, p.32

xiii. Okwu, V. G. (1975) 'The Establishment of Colonial Administration in Idomaland 1921 - 1930',Savannah, 5(1).

xiv. Seligman, C.C. (1930) Races of Africa, London: Kegan Paul Publishers.

xv. Smith, M.G. (1956) 'On Segmentary Lineage Systems', Journal of the Royal Anthropological Institute, Vol. 36, pp.38 - 80 .

xvi. Tseayo, J. I. (1975) 'Conflict and Incorporation in Nigeria: The Integration of the Tiv', Zaria: Gaskiya Corporation Ltd.

xvii. Wilk, I. (1978) 'African Historiographical Traditions, Old and New' in J. D. Fage (ed) Africa Discovers Her Past, London; Oxford University Press. 